\title{
Feather and blood meal in pre-starter and starter diets for broilers
}

\author{
Suzany Aparecida Gomes Xavier ${ }^{1}$, José Henrique Stringhini ${ }^{2,3}$, Alexandre Barbosa de Brito ${ }^{1}$, \\ Maria Auxiliadora Andrade ${ }^{4}$, Marcos Barcellos Café2,3, Nadja Susana Mogyca Leandro ${ }^{2,3}$
}

\footnotetext{
1 Pós-Graduação em Ciência Animal, Escola de Veterinária, Universidade Federal de Goiás.

2 Departamento de Produção Animal, Escola de Veterinária, Universidade Federal de Goiás.

${ }^{3}$ Bolsista do CNPq.

${ }^{4}$ Departamento de Medicina Veterinária, Escola de Veterinária, Universidade Federal de Goiás.
}

ABSTRACT - Two experiments were carried out (pre-starter and starter phases) to evaluate the effect of feather and blood meal on performance, organ development and digestibility and retention of nutrients in broilers. In the first experiment, it was used 280 birds and in experiment 2, it was used 240 birds. The experimental diets were formulated with four levels of feather and blood meal $(0 \%, 2 \%, 4 \%$ and $6 \%$ ) all of them isonutritive and isoenergetic. A metabolic assay was developed on the $4^{\text {th }}$ and $7^{\text {th }}$ days of age in experiment 1 and on the $14^{\text {th }}$ and $17^{\text {th }}$ days of age in experiment 2 . In these periods, one bird per experimental unit was sacrificed for determination of morphometry of the digestive organs. In experiment 1 , in which it was evaluated the pre-starter phase, there was a negative linear effect of the levels of feather and blood meal on weight gain and intake in 1-21 day of age period. By using feather and blood meal in the diet, it was observed a linear effect on digestibility coefficient of dry matter, nitrogen and ether extract; there was a quadratic effect on retention of dry matter and nitrogen and linear effect on the retention of ether extract. However, performance of birds in the starter phase (experiment 2) was not affected by levels of feather and blood meal used in the diet. Coefficient of digestibility of dry matter and ether extract and retention of ether extract were affected. In both phases, mortality and morphometric data of digestive organs were not influenced by the levels of meal in the diet. Formulation of diets with up to $6 \%$ feather and blood meal for chickens in the pre-starter phase (from 1 to 7 days) is not a good alternative because it worsens performance of birds. However, from the initial phase (from 8 to 21 days), the use of feather and blood meal in the diet is viable. Feather and blood meal can be used at levels 3.0 or $4.0 \%$ for broilers in the pre-starter and starter phase.

Key Words: animal origin meal, diets, digestibility, digestive development, performance

\section{Introdução}

Animal by-products supply nutrients with economic advantage for poultry diet formulation. Meanwhile, a challenge for nutritionists is the lack of uniformity of these ingredients, but each ingredient of animal origin has its specific nutritional characteristics (Rostagno et al., 2005).

Animal by-products in diet meets protein and mineral requirements, but they are not well balanced in amino acid content specially of the non-essential ones (MacLeod, 2001; Brugalli, 2002).

Xavier et al. (2004) observed that the use of ingredients of animal origin in pre-starter diet did not affect performance of broiler chicks from 1 to 21 days of age, but pancreas weight increased at 21 days of age. In the experiments performed by Longo et al. (2005), performance of chicks in pre-starter ration was not affected by the protein source fed, but this effect did not persist in the subsequent raising period. Rations containing these ingredients, when formulated based on ideal protein concept, result in better broiler performance (Cancherini et al., 2004; Bellaver et al., 2005).

The objectives of these experiments were to evaluate the performance of broilers fed pre-starter rations ( 1 to 7 days of age) and starter ( 8 to 21 days of age) formulated with different levels of feather and blood meal and their effects on nutrient digestibility and organ dimensions.

\section{Material and Methods}

The experiment was carried out in experimental poultry house in Escola de Veterinária e Zootecnia at Universidade Federal de Goiás, (EVZ/UFG), located in Goiânia, Goiás, and it was divided into two experiments to evaluate broilers in pre-starter phase (1 to 7 days) and starter phase (8 to 21 days ), respectively. The experimental period was from the $1^{\text {st }}$ to the $21^{\text {st }}$ days of age in assay 1 and from the $8^{\text {th }}$ to $21^{\text {st }}$ days of age in assay 2 .

A total of 280 broiler chicks were used in experiment 1 and other 240 birds in experiment 2, both from commercial 
line Avian Cobb $48^{\circledR}$. Birds were allotted in a completely randomized design with four levels of feather and blood meal, with five replicates in both experiments. Day-old chicks (male and female equally distributed) were grouped based on their weight in each treatment in five replicates of 14 birds, each one in experiment 1 . In experiment 2 , chicks (male and female equally distributed) were grouped based on their weight at the $8^{\text {th }}$ day of age in five replicates of 12 birds each.

The chicks were housed in four brooded batteries made by galvanized steel with five floors $(0.80 \mathrm{~m}$ length $\times$ $0.75 \mathrm{~m}$ width $\times 0.25 \mathrm{~m}$ height) and two floor divisions, installed in a facility of $12.96 \times 2.96 \mathrm{~m}\left(38.36 \mathrm{~m}^{2}\right)$ of internal dimensions, $2.32 \mathrm{~m}$ height and a roof covered with clay tiles. All facility is surrounded by a concrete wall of $0.46 \mathrm{~m}$ height and wire fence up to the roof at $1.70 \mathrm{~m}$ height, protected in the external area by plastic curtain and a driving ratchet to adequate the internal environment to birds comfort.

One week before the accommodation of birds, two days were used for cleanness and disinfection and five days for sanitary period for all equipments and facilities. The disinfectant used was based on quaternary ammonia and glutaraldehyde.
Each battery floor was warmed with $60 \mathrm{~W}$ incandescent lamps. Lights were maintained constantly on totaling 12 hours of natural illumination and 12 hours of artificial lights every day by $60 \mathrm{~W}$ incandescent lamps uniformly distributed in the facility. Linear feeders and drinkers were used, cleaned and supplied twice a day. The internal temperature was controlled by the lamps and external plastic curtains handling.

In both experiments, birds and rations were weighed at 1, 4, 7, 14-and 21 days of age in assay 1 (pre-starter phase evaluation) and at 8, 14, 17-and 21 days of age in assay 2 (pre-starter phase evaluation) and it was calculated the weight gain, the feed intake and the feed conversion.

The experimental diets were formulated by considering the levels of feather and blood meal proposed (0, 2, 4 and $6 \%)$ in pre-starter and starter diets for assay 1 and 2, respectively. In the formulation, the nutritional requirements and feed composition attended the data proposed by Brazilian tables (Rostagno et al., 2000) and they all were isonutritive and isoenergetic (Tables 1 and 2). In assay 1 , chicks received the experimental diets, containing feather and blood meal, at the first day of allotment and from the $8^{\text {th }}$ to the $21^{\text {st }}$ day of age, they received the same starter

Table 1 - Composition of pre-starter diets fed from 1 to 7 days of age (assay 1)

\begin{tabular}{|c|c|c|c|c|}
\hline \multirow[t]{2}{*}{ Ingredient $^{2}$} & \multirow[t]{2}{*}{ Control diet } & \multicolumn{3}{|c|}{ Feather and blood meal in diet } \\
\hline & & $2 \%$ & $4 \%$ & $6 \%$ \\
\hline Corn grain & 55.82 & 58.43 & 61.04 & 63.65 \\
\hline Soybean meal & 36.78 & 32.19 & 27.59 & 23.00 \\
\hline Wheat meal & 1.00 & 1.38 & 1.77 & 2.16 \\
\hline Dicalcium phosphate & 1.85 & 1.81 & 1.77 & 1.72 \\
\hline Limestone & 1.02 & 1.07 & 1.12 & 1.16 \\
\hline Soybean oil & 2.25 & 1.66 & 1.08 & 0.50 \\
\hline Feather and blood meal & 0.00 & 2.00 & 4.00 & 6.00 \\
\hline Common salt & 0.47 & 0.33 & 0.18 & 0.04 \\
\hline Mineral-vitamin supplement ${ }^{1}$ & 0.40 & 0.40 & 0.40 & 0.40 \\
\hline Sodium bicarbonate & 0.00 & 0.20 & 0.39 & 0.59 \\
\hline DL-methionine & 0.24 & 0.24 & 0.24 & 0.24 \\
\hline L-lysine $\mathrm{HCl}$ & 0.17 & 0.27 & 0.37 & 0.47 \\
\hline L-threonine & 0.00 & 0.01 & 0.02 & 0.02 \\
\hline L-tryptophan & 0.00 & 0.02 & 0.04 & 0.06 \\
\hline Nitrogen corrected apparent metabolizable energy (kcal/kg) & 2.950 & 2.950 & 2.950 & 2.950 \\
\hline Protein $(\%)$ & 22.00 & 22.00 & 22.00 & 22.00 \\
\hline Digestible lysine (\%) & 1.18 & 1.18 & 1.18 & 1.18 \\
\hline Digestible methionine + cystine (\%) & 0.83 & 0.83 & 0.83 & 0.83 \\
\hline Digestible threonine (\%) & 0.74 & 0.74 & 0.74 & 0.74 \\
\hline Digestible tryptophan (\%) & 0.25 & 0.25 & 0.25 & 0.25 \\
\hline Calcium (\%) & 0.99 & 0.99 & 0.99 & 0.99 \\
\hline Available phosphorus (\%) & 0.46 & 0.46 & 0.46 & 0.46 \\
\hline Potassium (\%) & 0.85 & 0.79 & 0.72 & 0.65 \\
\hline Sodium (\%) & 0.23 & 0.23 & 0.23 & 0.23 \\
\hline Chloride (\%) & 0.36 & 0.32 & 0.29 & 0.25 \\
\hline Mongin number (mEq/kg) & 216 & 216 & 216 & 216 \\
\hline
\end{tabular}


Table 2 - Composition of starter diets fed from 8 to 21 days of age (assay 2)

\begin{tabular}{|c|c|c|c|c|}
\hline \multirow[t]{2}{*}{ Ingredient } & \multirow[t]{2}{*}{ Control diet } & \multicolumn{3}{|c|}{ Feather and blood meal in diet } \\
\hline & & $2 \%$ & $4 \%$ & $6 \%$ \\
\hline Corn grain & 58.29 & 61.44 & 64.63 & 67.59 \\
\hline Wheat meal & 1.50 & 1.51 & 1.51 & 1.50 \\
\hline Dicalcium phosphate & 1.76 & 1.73 & 1.69 & 1.65 \\
\hline Limestone & 0.98 & 1.03 & 1.07 & 1.10 \\
\hline Soybean oil & 2.57 & 1.88 & 1.17 & 0.47 \\
\hline Mineral-vitamin supplement ${ }^{1}$ & 0.40 & 0.40 & 0.40 & 0.40 \\
\hline Sodium bicarbonate & 0.00 & 0.08 & 0.17 & 0.25 \\
\hline DL-methionine & 0.22 & 0.22 & 0.22 & 0.22 \\
\hline L-lysine $\mathrm{HCl}$ & 0.18 & 0.28 & 0.38 & 0.48 \\
\hline L-threonine & 0.00 & 0.01 & 0.01 & 0.02 \\
\hline L-tryptophan & 0.00 & 0.02 & 0.04 & 0.06 \\
\hline Digestible threonine (\%) & 0.69 & 0.69 & 0.69 & 0.69 \\
\hline Digestible tryptophan (\%) & 0.23 & 0.23 & 0.23 & 0.23 \\
\hline Calcium (\%) & 0.94 & 0.94 & 0.94 & 0.94 \\
\hline Available phosphorus (\%) & 0.44 & 0.44 & 0.44 & 0.44 \\
\hline Potassium $(\%)$ & 0.81 & 0.77 & 0.74 & 0.70 \\
\hline Sodium (\%) & 0.22 & 0.22 & 0.22 & 0.22 \\
\hline Chloride (\%) & 0.35 & 0.31 & 0.28 & 0.25 \\
\hline Mongin number (mEq/kg) & 203 & 203 & 202 & 202 \\
\hline
\end{tabular}

diet, formulated with vegetable origin ingredients. In assay 2 , all the birds were fed the same pre-starter diet from the $1^{\text {st }}$ to the $7^{\text {st }}$ day of age formulated with vegetable origin ingredients and, from the $8^{\text {th }}$ to the $21^{\text {st }}$ day of age, they were fed the experimental diets with feather and blood meal.

In both experiments, broiler and diets were weighed and mortality were registered. Data was processed to calculate the performance variables (weight gain, feed intake, feed conversion and mortality (transformed to arc sen (\%/100)0.5 for statistical analysis)).

From the $4^{\text {th }}$ to the $7^{\text {th }}$ days of age, in assay 1 , and from the $14^{\text {th }}$ to the $17^{\text {th }}$ days of age in assay 2 , the metabolic assays were performed. Total excreta collection method was used, twice a day, during the experimental period. Experimental diets and excreta collected were frozen for conservation.

Afterwards, the processed excreta and experimental feeds were submitted to laboratory analysis in the Laboratório de Nutrição Animal at the EVZ/UFG to determine dry matter (DM), crude protein (CP) and ether extract (EE), according to the methodology described by Silva \& Queiroz (2002). When the results of DM, CPPB and EE were obtained, they were used to calculate the digestibility coefficient (DC\%) by using the formula described by Matterson et al. (1965):

DC $(\%)=\underline{\text { Feed nutrient ingested }- \text { Nutrient excreted } \times 100}$ Feed nutrient ingested

Nutrient retention analysis was performed according to Noy \& Sklan (2002), in which the nutrient balance (ingested minus excreted) and weight gain obtained from 4 to 7 days and from 14 to 17 days of age in experiments 1 and 2, respectively. At 4 and 7 days of age and at 14 and 17 days of age, one chick was selected according to the mean weight gain per replicate and transported to the Avian Diseases and Production Section Laboratory of EVZ/UFG for morphometric measuring. Selected birds were fasted for 6 hours and then weighed and euthanized by cervical dislocation and extracted esophagus + crop, proventriculus + gizzard, small intestine, pancreas, liver with gall bladder and total intestine were weighed. The total intestine height was determined. Data was obtained and then related to live weight and expressed in percentage.

The statistical analysis was performed by SAEG program (UFV, 2000) and polynomial regression until the $3^{\text {rd }}$ degree was used. 


\section{Results and Discussion}

Mean temperature and relative humidity measured in the experimental facility for both experiments were $30.8 \pm 1.3^{\circ} \mathrm{C}$ and $58.2 \pm 4.5^{\circ} \mathrm{C}$, considered adequate for broiler rearing in the geographic region where the experiments were carried out.

The day-old chick weight, in assay 1, was $46.2 \pm 0.3 \mathrm{~g}$ and, in assay 2, it was $187.2 \pm 0.9 \mathrm{~g}$ at 7 days of age. In prestarter phase, the levels of feather and blood meal did not affect $(\mathrm{P}>0.05)$ weight gain, feed intake and feed conversion of broilers (Table 3). However, in total period, a negative linear effect $(\mathrm{P}<0.05)$ on weight gain and feed intake, which indicates that the highest levels of feather and blood meal in pre-starter diets resulted in a significant reduction in broiler performance. No effect was observed for mortalilty rate in assay 1.

In the metabolic assay performed in experiment 1 (Table 4), the increasing feather and blood meal levels influenced $(\mathrm{P}<0.05)$ the coefficient of digestibility of dry matter $(\mathrm{Y}=71.816+0.487182 \mathrm{X})$, of nitrogen $(\mathrm{Y}=64.6119$ $-0.677149 \mathrm{X})$ and of ether extract $(\mathrm{Y}=907.894+49.8558 \mathrm{X}$ $\left.-6.78413 X^{2}\right)$. Calculating the differential coefficient for the quadratic equation, the maximum points estimated were $3.7 \%$ of feather and blood meal inclusion in rations for coefficient of digestibility of ether extract. Despite the higher levels obtained for digestibility of dry matter, a reduction in nitrogen and fat in broilers occurred, which partially explain the worst performance data observed.

By evaluating the nutrient retention data obtained in pre-starter phase (Table 4), the increased feather and blood meal levels affected $(\mathrm{P}<0.05)$ the retention of dry matter $\left(Y=192.412+5.51828 X-1.5838 X^{2}\right)$, of nitrogen $(\mathrm{Y}=49.2202-1.02093 \mathrm{X})$ and of ether extract $(\mathrm{Y}=78.3325$ - $0.8120488 \mathrm{X}$ ). And by calculating the differential coefficient for the quadratic equation, the maximum points estimated were $1.7 \%$ of feather and blood meal inclusion in rations for retention of dry matter. No effect of feather and blood meal increasing levels $(\mathrm{P}>0.05$ ) were observed in the measuring of digestive organs obtained in prestarter phase (Table 5).

In assay 2, the feather and blood meal levels did not influence $(\mathrm{P}>0.05$ ) broiler performance (Table 6$)$. The feather and blood meal levels tested did not affect mortality in the analyzed period.

By analyzing the results of the metabolic assay in experiment 2 (Table 7), the feather and blood meal levels affected $(\mathrm{P}<0.05)$ the digestibility coefficient of dry matter

Table 3 - Performance of broiler fed diets containing increasing levels of feather and blood meal in pre-starter diet (assay 1)

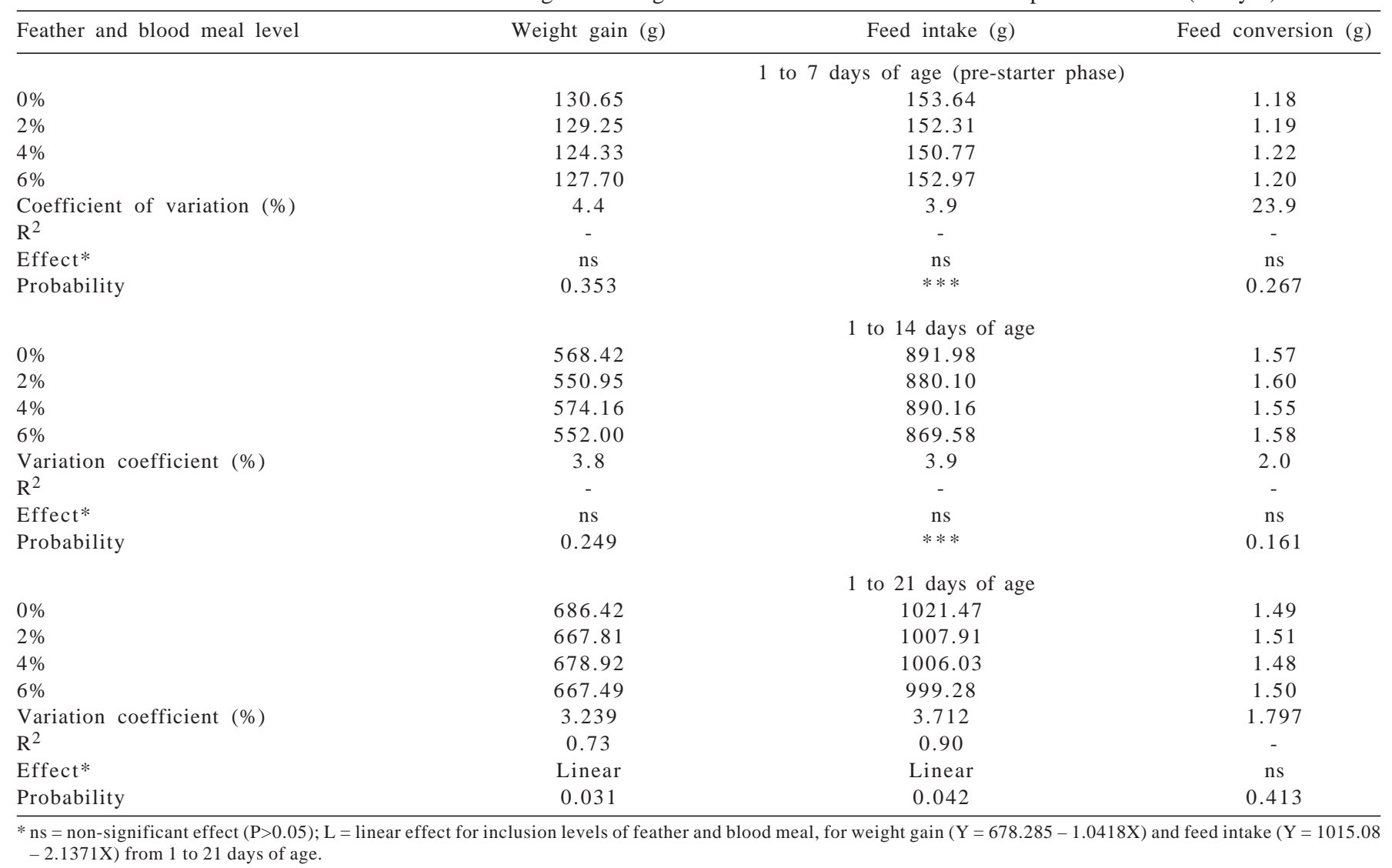


$\left(\mathrm{Y}=74.823+1.35686 \mathrm{X}-0.151466 \mathrm{X}^{2}\right)$ and of the ether $\operatorname{extract}\left(\mathrm{Y}=81.9576+1.92053 \mathrm{X}-0.647589 \mathrm{X}^{2}\right)$.

By calculating the differential coefficient for quadratic regression, the points for maximum digestibility of dry matter and digestibility and retention of ether extract were $4.5 \%$ and $1.5 \%$ of feather and blood meal, respectively. When nutrient retention was evaluated in experiment 2 (Table 7), the levels of feather and blood meal influenced $(\mathrm{P}<0.05)$ the retention of ether extract $(\mathrm{Y}=64.0332+2.644568$ $\left.-1.27145 \mathrm{X}^{2}\right)$. It was possible to estimate $1.0 \%$ of feather and blood meal as the best value for ether extract retention.

For the digestive organs dimensions obtained in experiment 2 (Table 8), no effect was observed for the increasing feather and blood meal levels tested in diets for the starter phase $(\mathrm{P}>0.05)$.

The higher levels of feather and blood meal tested in diet resulted in a gradual reduction in broiler performance in the starter phase, but the differences obtained were not significant.
The formulation of rations based on ideal protein proposed by Baker \& Han (1994) became more efficient when alternative ingredients for corn and soybean meal were used. Thus, animal origin by-products are an important alternative, mainly in companies with vertical integration systems as it occurs in Brazil, where these products are available in great amounts, with reduced cost, which makes their use in rations economically viable. But, the use of great amount of these ingredients in diets is possible only when the main essential amino acids for poultry are considered, by keeping the desired performance levels (Wang \& Parsons, 1998b).

The experiments conducted by Mendonza et al. (2001) and Rostagno et al. (1995), with diets formulated on base of digestible aminoacids resulted in better feed conversion and weight gain compared to the ones formulated with crude protein. Using animal origin by-products, Wang \& Parsons (1998a) demonstrated that the inclusion of 10 to $20 \%$ of meat and bone meal, considered by the authors as

Table 4 - Digestibility and retention coefficients of nutrients obtained from 4 to 7 days of age in broiler fed diets containing increasing levels of feather and blood meal

\begin{tabular}{|c|c|c|c|c|c|c|}
\hline \multirow[t]{2}{*}{ Feather and blood meal level } & \multicolumn{3}{|c|}{ Digestibility coefficient (\%) } & \multicolumn{3}{|c|}{ Retention coefficient (mg/g) } \\
\hline & Dry matter & Nitrogen & Ether extract & Dry matter & Nitrogen & ether extract \\
\hline $0 \%$ & 71.64 & 65.42 & 914.42 & 200.34 & 48.68 & 78.10 \\
\hline $2 \%$ & 73.30 & 61.11 & 960.89 & 173.34 & 47.81 & 78.16 \\
\hline $4 \%$ & 73.26 & 63.81 & 1018.35 & 212.92 & 45.49 & 72.89 \\
\hline $6 \%$ & 74.91 & 60.04 & 956.28 & 160.58 & 42.65 & 74.44 \\
\hline Coefficient of variation (\%) & 1.20 & 4.19 & 2.69 & 4.22 & 5.463 & 3.20 \\
\hline $\mathrm{R}^{2}$ & 0.89 & 0.50 & 0.63 & 0.84 & 0.28 & 0.95 \\
\hline Effect* & Linear & Linear & Quadratic & Quadratic & Linear & Linear \\
\hline Probability & 0.001 & 0.021 & 0.001 & 0.009 & 0.013 & 0.001 \\
\hline
\end{tabular}

*NS = non-significant effect $(\mathrm{P}>0.05)$.

Table 5 - Digestive organ relative weight and intestine height for broiler fed diets containing increasing levels of feather and blood meal in pre-starter phase

\begin{tabular}{|c|c|c|c|c|c|c|}
\hline \multirow[t]{2}{*}{ Feather and blood meal level } & \multirow{2}{*}{$\begin{array}{l}\text { Intestine } \\
\text { height }(\mathrm{cm})\end{array}$} & \multicolumn{4}{|c|}{ Relative weight (\%) } & \multirow[b]{2}{*}{ Small intestine } \\
\hline & & Esophagus + crop & Proventriculus + gizzard & Liver & Pancreas & \\
\hline & \multicolumn{6}{|c|}{4 days of age } \\
\hline $2 \%$ & 83.20 & 1.63 & 9.17 & 4.49 & 0.42 & 6.76 \\
\hline $4 \%$ & 86.40 & 1.78 & 8.62 & 4.51 & 0.48 & 6.58 \\
\hline $6 \%$ & 81.40 & 1.55 & 8.93 & 4.83 & 0.48 & 6.56 \\
\hline Effect* & ns & ns & ns & $\mathrm{ns}$ & ns & ns \\
\hline \multirow[t]{2}{*}{ Probability } & 0.415 & $* * *$ & $* * *$ & $* * *$ & $* * *$ & 0.254 \\
\hline & \multicolumn{6}{|c|}{7 days of age } \\
\hline $0 \%$ & 89.56 & 1.10 & 7.19 & 3.86 & 0.46 & 6.61 \\
\hline $2 \%$ & 85.62 & 1.02 & 7.12 & 3.87 & 0.47 & 5.89 \\
\hline $4 \%$ & 90.04 & 1.16 & 6.96 & 3.76 & 0.47 & 6.00 \\
\hline Probability & 0.152 & 0.405 & $* * *$ & $* * *$ & $* * *$ & 0.145 \\
\hline
\end{tabular}

*ns = non-significant effect $(\mathrm{P}>0.05)$. 
high or low quality, in corn-soybean meal based diets, formulated based in total amino acids, the weight gain and feed efficiency got worst. Meanwhile, when diets were calculated based in digestible amino acids, the use of $10 \%$ of low quality meat and bone meal or 10 to $20 \%$ of high quality meat and bone meal did not affect animal performance.
A factor that could explain the best broiler performance is feed intake, which did not depend only on the amount of crude protein, but also on its quality, which can be attributed to the best amino acid balance, which can justify the use of ideal protein concept (Bellaver et al., 2001).

When soybean meal was substituted by feather and viscera meal in broiler diets, Klemesrud et al. (1997)

Table 6 - Performance of broilers fed diets containing increasing levels of feather and blood meal in pre-starter phase

\begin{tabular}{|c|c|c|c|}
\hline Feather and blood meal level & Weight gain (g) & Feed intake (g) & Feed conversion (g) \\
\hline $0 \%$ & 546.07 & 954.49 & 1.75 \\
\hline $2 \%$ & 523.45 & 945.78 & 1.81 \\
\hline $4 \%$ & 520.88 & 923.82 & 1.77 \\
\hline $6 \%$ & 519.21 & 937.74 & 1.81 \\
\hline Variation coefficient (\%) & 4.028 & 3.154 & 3.141 \\
\hline $\mathrm{R}^{2}$ & - & - & - \\
\hline Effect* & ns & ns & ns \\
\hline Probability & 0.197 & $* * *$ & 0.292 \\
\hline
\end{tabular}

*ns = non-significant effect $(\mathrm{P}>0.05)$.

Table 7 - Digestibility and retention coefficients of nutrients obtained from broilers at 14 to 17 days of age fed diets containing increasing levels of feather and blood meal

\begin{tabular}{|c|c|c|c|c|c|c|}
\hline \multirow[t]{2}{*}{ Feather and blood meal level } & \multicolumn{3}{|c|}{ Digestibility coefficient (\%) } & \multicolumn{3}{|c|}{ Retention coefficient (mg/g) } \\
\hline & Dry matter & Nitrogen & Ether extract & Dry matter & Nitrogen & ether extract \\
\hline $0 \%$ & 74.20 & 64.59 & 1267.57 & 265.23 & 63.83 & 82.46 \\
\hline $2 \%$ & 76.24 & 64.40 & 1407.30 & 273.69 & 64.83 & 81.71 \\
\hline $4 \%$ & 77.24 & 65.65 & 1363.55 & 264.91 & 53.67 & 80.77 \\
\hline $6 \%$ & 76.85 & 64.89 & 1367.38 & 272.46 & 34.33 & 69.67 \\
\hline Coefficient of variation (\%) & 1.582 & 3.113 & 3.859 & 8.845 & 10.101 & 9.797 \\
\hline $\mathrm{R}^{2}$ & 0.99 & - & 0.95 & - & - & 0.99 \\
\hline Effect* & Q & ns & Q & ns & ns & Q \\
\hline Probability & 0.039 & $* * *$ & 0.001 & 0.331 & $* * *$ & 0.001 \\
\hline
\end{tabular}

*ns = non-significant effect $(\mathrm{P}>0.05) ; \mathrm{Q}=$ quadratic effect of levels of feather and blood meal.

Table 8 - Digestive organ relative weight and intestine height for broiler fed diets containing increasing levels of feather and blood meal in pre-starter phase

\begin{tabular}{|c|c|c|c|c|c|c|}
\hline \multirow[t]{2}{*}{ Feather and blood meal levels } & \multirow{2}{*}{$\begin{array}{c}\text { Intestine } \\
\text { height }(\mathrm{cm})\end{array}$} & \multicolumn{4}{|c|}{ Relative weight (\%) } & \multirow[b]{2}{*}{ Small intestine } \\
\hline & & Esophagus + crop & Proventriculus + gizzard & Liver & Pancreas & \\
\hline & & & 14 days of age & & & \\
\hline $0 \%$ & 118.20 & 0.88 & 5.01 & 3.29 & 0.33 & 4.69 \\
\hline $2 \%$ & 112.60 & 0.88 & 4.91 & 3.37 & 0.38 & 4.34 \\
\hline $4 \%$ & 116.40 & 0.76 & 4.76 & 2.92 & 0.36 & 3.86 \\
\hline $6 \%$ & 120.80 & 0.88 & 4.58 & 3.90 & 0.40 & 4.22 \\
\hline Variation coefficient (\%) & 7.579 & 17.874 & 10.300 & 22.216 & 11.905 & 19.615 \\
\hline $\mathrm{R}^{2}$ & - & - & - & - & - & - \\
\hline Effect* & ns & ns & ns & ns & ns & ns \\
\hline \multirow[t]{2}{*}{ Probability } & $* * *$ & $* * *$ & $* * *$ & 0.266 & 0.104 & 0.070 \\
\hline & & & 17 days of age & & & \\
\hline $0 \%$ & 113.80 & 0.87 & 4.41 & 2.89 & 0.31 & 3.83 \\
\hline $2 \%$ & 120.40 & 0.84 & 4.40 & 2.87 & 0.30 & 2.80 \\
\hline $4 \%$ & 111.00 & 0.87 & 4.27 & 2.92 & 0.33 & 4.20 \\
\hline $6 \%$ & 104.00 & 0.86 & 4.59 & 2.77 & 0.33 & 3.97 \\
\hline Coefficient of variation (\%) & 9.233 & 20.313 & 11.423 & 6.755 & 14.099 & 9.242 \\
\hline $\mathrm{R}^{2}$ & - & - & - & - & - & - \\
\hline Effect* & ns & ns & ns & ns & ns & ns \\
\hline Probability & 0.134 & $* * *$ & $* * *$ & $* * *$ & $* * *$ & $* * *$ \\
\hline
\end{tabular}

*ns = non-significant effect $(\mathrm{P}>0.05)$. 
concluded that the formulation based on ideal protein in starter ( 1 to 21 days of age) and final phases (22 to 42 days of age) did not affect performance when feather and viscera meal represented $4 \%$ in diet. However, in higher substitution levels, the worst results were observed in the starter phase, which was attributed by the the authors to the immaturity of gastrointestinal tract of the birds, which influenced protein digestion of animal by-products, because all diets were formulated in ideal protein concept.

The important point related to the utilization of alternative protein sources in diets is that, when the amino acids are in excess, the deamination occurs and the nitrogen is excreted as uric acid by birds, which implies in extra energy waste, reinforcing the importance of the knowledge of amino acid and energy composition of the ingredient (Bellaver, 2001).

The performance reduction observed in this experiment can be related to the age in which the animals consumed the experimental rations (pre-starter and starter phases). The digestion and absorption of nutrients in pre-starter phase depends on the presence of the digestive enzymes synthesized mainly in the pancreas. Proteolityc enzymes in broilers increased the amount secreted with age (Krogdahl \& Sell, 1989; Nitsan et al., 1991; Parsons et al., 1998; Noy \& Sklan, 2002). According to Alleman et al. (2000), the vegetable origin protein source has a complex structure which limits the enzymatic secretion and makes the protein digestion and absorption difficult for broilers.

The higher inclusion of feather and blood meal resulted in increased digestibility of dry matter which may be a result of the inclusion of corn that is superior to other diets. These results are attributed to carbohydrate digestibility, which is relatively higher and simpler compared to protein. As the inclusion of animal by-products increase, ether extract digestion and absorption seems to reduce, but this fact can be a result of lower vegetable oil amount in diets. When using the slaughterhouse residues, Gaiotto et al. (2000) verified that the nitrogen corrected apparent metabolizable energy (EMAn) in pre-starter and starter phases for viscera poultry oil in pre-starter phases was lower than in the other phases. Other factor which collaborates to the reduction of ether extract fraction can be attributed to the immaturity of the enterohepatic circulation in post-hatch chicks which implicates in lower digestion and absorption of lipids (Moran Junior, 1994; Furlan \& Macari, 2002).

No differences in organ weight and intestine height was observed, differing from the results obtained by Xavier et al. (2004) and Longo et al. (2005) with protein sources at different levels, but, in these experiments only one source was compared at lower levels of inclusion compared to the authors cited above.

The utilization of animal origin by-products, specially poultry slaughterhouse residues, can be viable, but their production needs to be done to guarantee the higher quality at moderate amounts, however. According to Penz Junior et al. (2005), the most visible damage that can occur with the non-utilization of animal by-products is the increased production costs. More than that, the authors reinforce that the reduction in the inclusion of these ingredients results in higher levels of vegetable oil and soybean meal, a 10\% increase in feeding costs. These ingredients contain amino acids, energy, calcium and phosphorus in balanced amounts. In practical view, for nutritionists, animal origin by-products and fats which are substituted by vegetable oil, soybean meal and dicalcium phosphate and other supplements can result in higher feeding costs (Bellaver et al., 2005).

\section{Conclusions}

Feather and blood meal can be recommended at 3.0 to $4.0 \%$ in broiler pre-starter and starter rations.

\section{References}

ALLEMAN, F.; MICHEL, J.; CHANGNEU, A.M. et al. The effects of dietary protein independent of essential amino acids on growth and body compositions in genetically lean and fat chickens. British Poultry Science, v.41, p.214-218, 2000.

BAKER D.H.; HAN, Y. Ideal amino acid profile for chicks during the first three weeks posthatching. Poultry Science, v.73, p.1441-1447, 1994.

BELLAVER, C. Ingredientes de origem animal destinados à fabricação de rações. In: SIMPÓSIO SOBRE INGREDIENTES NA AlimentaÇÃO ANimAL, 2001, Campinas. Anais... Campinas: CBNA, 2001. p.167-190.

BELLAVER, C.; BRUM, P.A.R.; LIMA, G.M.M. et al. Substituição parcial do farelo de soja pela farinha de vísceras de aves em dietas balanceadas com base na proteína e em aminoácidos totais ou digestíveis para frangos de corte. Revista Brasileira de Ciência Avícola, v.3, n.3, p.233-240, 2001.

BELLAVER, C.; COSTA, C.A.F.; AVILA, V.S. et al. Substituição de farinhas de origem animal por ingredientes de origem vegetal em dietas para frangos de corte. Ciência Rural, v.35, n.3, p.671-677, 2005.

BRUGALLI, I. Variação de aminoácidos nos ingredientes importância prática e aplicação do NIRS para controlar a variabilidade. In: SIMPÓSIO SOBRE INGREDIENTES NA ALIMENTAÇÃO ANIMAL, 2002, Uberlândia. Anais... Campinas: CBNA, 2002. v.2, p.277-284.

CANCHERINI, L.C.; JUNQUEIRA, O.M.; ANDREOTTI, M.O. et al. Utilização de subprodutos de origem animal em dietas para frangos de corte com base em proteínas bruta e ideal, no período de 43 a 49 days of age. Revista Brasileira de Zootecnia, v.33, n.6, p.2060-2065, 2004 (supl.2).

FURLAN, R.L.; MACARI, M. Lipídios: digestão e absorção. In: MACARI, M.; FURLAN, R.L.; GONZALES, E. (Eds.) Fisiologia aviária aplicada a frangos de corte. Jaboticabal: FUNEP, 2002. p.143-148. 
GAIOTTO, J.B.; MENTEN, J.F.M.; RACANICCI, A.M.C. Óleo de soja, óleo ácido de soja e sebo bovino como fontes de gordura em rações de frangos de corte. Revista Brasileira de Ciência Avícola, v.2, p.219-227, 2000.

KLEMESRUD, M.J.; KLOPFENSTEIN, T.J.; LEWIS, A.J. et al. Limiting amino acids in meat and bone and poultry by-product meals. Journal of animal science, v.75, n.12, p.3294-3300, 1997.

KROGDAHL, A.; SELL, J. Influence of age on lípase, amylase and protease activities on pancreatic tissue and intestinal contents of young turkeys. Poultry Science, v.68, p.1561-1568, 1989.

LONGO, F.A.; MENTEN, J.F.M.; PEDROSO, A.A. et al. Diferentes fontes de proteína na dieta pré-inicial de frangos de corte. Revista Brasileira de Zootecnia, v.34, n.1, p.112-122, 2005.

MacLEOD, M.G. Effect do balanço entre aminoácidos e a relação energia/proteína sobre o seu metabolismo: desempenho e composição corporal em frangos de corte. In: SIMPÓSIO INTERNACIONAL ACAV DE NUTRIÇÃO DE AVES, 2., 2001, Concórdia. Anais... Concórdia: EMBRAPA, 2001. p.64-81.

MATTERSON, L.D.; POTTER, L.M.; STUTZ, M.W. et al. The metabolizable energy of feeds ingredients for chickens. Connecticut: University of Connecticut Press, 1965. 11p.

MENDONZA, M.O.B.; COSTA, P.T.C.; KATZER, L.H. Desempenho de frangos de corte, sexados, submetidos a dietas formuladas pelos conceitos de proteína bruta versus proteína ideal. Ciência Rural, v.31, p.111-115, 2001.

MORAN JUNIOR, E.T. Digestão e absorção de gorduras. In: FACTA. Fisiologia da digestão e absorção das aves. Campinas: FACTA, 1994. p.71-82.

NITSAN, Z.; BEN-AVRAHAM, G.; ZOREF, Z. et al. Growth and development of the digestive organs and some enzymes in broiler chicks after hatching. British Poultry Science, v.32, p.515-23, 1991.

NOY, Y.; SKLAN, D. Nutrient use in chicks during the first week posthatch. Poultry Science, v.81, p.391-399, 2002.
PARSONS, C.M.; ZHANG, Y.; ARABA, M. Development of the digestive tract of poultry. Poultry Science, v.77, p.1016-1019, 1998.

PENZ JUNIOR, A.M.; DARI, R.L.; SHIROMA, N. Consequências das dietas formuladas sem proteínas de origem animal. In: CONFERÊNCIA APINCO DE CIÊNCIA E TECNOLOGIA AVÍCOLAS, 2005, Santos. Anais... São Paulo: FACTA, 2005. p.249-256.

ROSTAGNO, H.S.; ALBINO, L.F.T.; DONZELE, J.L. et al. Tabelas brasileiras para aves e suínos: composição de alimentos e exigências nutricionais. Viçosa, MG: UFV - Imp. Univ., 2000. 61p.

ROSTAGNO, H.S.; ALBINO, L.F.T.; DONZELE, J.L. et al. Tabelas brasileiras para aves e suínos: composição de alimentos e exigências nutricionais. Viçosa, MG: UFV Imprensa Universitária, 2005. 186p.

ROSTAGNO, H.S.; PUPA, J.M.R.; PACK, M.J. Diet formulation for broilers based on total versus digestible amino acids. Journal of Applied Poultry Research, v.64, p.119-126, 1995.

SILVA, D.J; QUEIROZ, A.C. Análise de alimentos: métodos químicos e biológicos. 3.ed. Viçosa, MG: Editora UFV, 2002. 235p.

UFV/SAEG. Sistema de análises estatísticas e genéticas Versão 7.1. Viçosa, MG: 2000. 150p. [Manual do usuário].

WANG, X.; PARSONS, C.M. Dietary.formulation with meat and bone meal on total verus a digestible or bioavailable amino acid basis. Poultry Science, v.77, p.1010-1015, 1998a.

WANG, X.; PARSONS, C.M. Order of amino acid limitation in poultry by-product meal. British Poultry Science, v.39, n.1, p.113-116, 1998b.

XAVIER, S.A.G.; STRINGHINI, J.H.; BRITO, A.B. et al. Digestibilidade e retenção de nutrientes de frangos de corte consumindo dietas com diferentes fontes protéicas na fase pré-inicial. Revista Brasileira de Ciência Avícola, supl.6, p.83, 2004 